\title{
Companies' Financial Security Mechanism under Hybrid Conflicts
}

\author{
Lesya Yastrubetska ${ }^{1, *}$, Ihor Krupka ${ }^{2}$, Viktor Kovalenko ${ }^{1}$, Nataliia Zhmurko ${ }^{1}$, \\ Olesia Mykuliak ${ }^{1}$
}

\begin{abstract}
${ }^{1}$ Department of Finance, Money Circulation and Credit, Ivan Franko National University of Lviv, Ukraine ${ }^{2}$ Department of Analytical and International Economics, Ivan Franko National University of Lviv, Ukraine
\end{abstract}

Received October 12, 2021; Revised November 18, 2021; Accepted December 22, 2021

\begin{abstract}
Cite This Paper in the following Citation Styles
(a): [1] Lesya Yastrubetska, Ihor Krupka, Viktor Kovalenko, Nataliia Zhmurko, Olesia Mykuliak, "Companies' Financial Security Mechanism under Hybrid Conflicts, "Universal Journal of Accounting and Finance, Vol. 10, No. 1, pp. 113-123, 2022. DOI: 10.13189/ujaf.2022.100112.
\end{abstract}

(b): Lesya Yastrubetska, Ihor Krupka, Viktor Kovalenko, Nataliia Zhmurko, Olesia Mykuliak (2022). Companies' Financial Security Mechanism under Hybrid Conflicts. Universal Journal of Accounting and Finance, 10(1), 113-123. DOI: 10.13189/ujaf.2022.100112.

Copyright $\bigcirc 2022$ by authors, all rights reserved. Authors agree that this article remains permanently open access under the terms of the Creative Commons Attribution License 4.0 International License

\begin{abstract}
This scientific article is devoted to the development of the mechanism of companies' financial security management and measures to improve it under the hybrid conflict. The study is conducted on the prerequisites of Ukrainian companies operating in the zone of hybrid conflict. The study aims to develop a mechanism for managing the financial security of Ukrainian companies operating under hybrid conflicts. Insufficient scientific research on improving companies' financial security under hybrid warfare and the government's imperfect regulation of financial security makes the topic relevant for scientific research. The academic paper highlights the theory that whilst the hybrid conflict weakens the level of financial security of the company improves. Statistical and mathematical methods of calculations are used to carry out empirical research. The correlation between the peace index and the index of financial security of Ukraine is determined. The article's novelty involves the development of risks classification associated with non-military actions affecting the companies' financial security management. The financial security management mechanism's functional components have been developed in the research; the steps to improve financial security have been outlined. Two directions of development of financial security management, based on changes in the geographical location of the enterprise and the continuation of work in a hybrid conflict, are proposed. Contentious views have confirmed the fact that changing the enterprise's geolocation is less widespread; consequently, the proposed
\end{abstract}

directions for the development of financial security are of practical importance for business in the temporarily occupied territories.

Keywords Hybrid Conflict, Peace Index, Financial Security, Temporarily Occupied Territories, Financial Risks

\section{Introduction}

Studies of the companies' financial security management problems in Ukraine have become relevant in the last six years. However, this is due to the emergence of hybrid warfare in Ukraine as the main prerequisite for relevance. To this day, the problems of normative and theoretical formation of the enterprise's financial security mechanism remain unsolved [21]. The only normative document in Ukraine defining the concept of security is the Law "On the Fundamentals of National Security of Ukraine." Most economists, financiers, and practicing people in business believe that financial security is one of the components of the economic security system and it is one of the principal ones. Domestic and foreign scholars define financial security as a state of protection of companies' financial interests from actual and potential threats of external and internal nature, ensuring the subject of preservation and growth of its market value [22]. In a 
hybrid conflict, there are all possible threats in both external and internal environments. As a result, companies should work in complex and sometimes force majeure conditions accompanied by significant risks. Currently, taking into consideration that there is constant military action in the world, the problem of supporting businesses that are territorially in the conflict zone is constantly relevant $[19,18,12]$. At the same time, taking into consideration that in force majeure, companies cannot rely on government support, they are forced to build business models that will withstand crises or save the founders' capital. This fact determines the primary study's relevance forasmuch as companies experience an acute lack of practical recommendations for financial security under hybrid conflicts. The study aims to develop a mechanism for managing the financial security of Ukrainian enterprises operating in conditions of hybrid conflicts.

\section{Literature Review}

Numerous scientific studies worldwide are devoted to building models for managing the state's financial security during the war. As for the hybrid conflict, it has some different features from military action. Terminological dictionaries define hybrid war as a war, the main tool of which is the creation by the aggressor state of internal contradictions and conflicts in the country chosen for aggression. The political goals of aggression are achieved through political warfare [5]. The definition of the term "hybrid warfare" is almost similar, but broader; it means a military strategy combining conventional warfare, small warfare, or cyberwarfare. The term "hybrid warfare" also describes attacks using nuclear, biological, and chemical weapons, improvised explosive devices, and information technology. In turn, the concept of hybrid conflict emerged in 2005 after US Secretary of Defense James Mattis and Lt. Col. Frank Hoffman used the term in a document called "The Future War: The Rise of Hybrid Wars". In this document, the main characteristics of this type of conflict are psychological or informational operational aspects that are combined with traditional hostilities [7]. This approach to conflict is a powerful and complex form of war. Sometimes this term is used to describe the complex dynamics of the combat space, involving a flexible response and requiring rapid adaptation [6]. In the context of the impact of hostilities on business development, it is appropriate to highlight the numerous works of Rettberg A. [20], who attached great importance of business as the primary tool for resolving state conflicts in Colombia. By creating socially essential products, they can put political, economic, and social pressure on militants. After the outbreak of the military conflict in Ukraine in 2014, this topic began to be actively studied by Ukrainian scholars. At the same time, most media outlets highlight the term hybrid rather than military for research on this topic. Varnalii Z. and Tomashevskij T. [1] identified the main problems of building financial security of Ukraine under the conditions of a hybrid war, clarified the concept of financial security and its place in the overall economic security of the country. The biggest problem of Ukraine, according to the authors' viewpoint, is the shadowing of the economy, which does not allow providing an effective mechanism of financial security in a hybrid war. There are also studies related to the preconditions for doing business under the conditions of a hybrid war. It is worth highlighting the article by Kravchenko \& Pinchuk [2], which examines the prerequisites for doing business under hybrid conflict in eastern Ukraine based on the global peace index analysis. This index reflects the level of countries' tension; it has been revealed that during 2014-2019 Ukraine was in the TOP-20 most unstable countries in the world. The authors show that hybrid conflicts affect macroeconomic indicators and market environment indicators, particularly indicators of entrepreneurial activity and ease of doing business and business confidence of the industry. Zachosova N. [4] identified the impact of hybrid conflict on the financial institution. The author noted that in the context of hybrid conflicts, there is a destabilization of financial institutions that are counterparties or partners of banks with Russian capital. For this reason, many bank clients, including legal entities, cannot recover their invested capital in the occupied territories without the involvement of intermediaries. Due to the fall of the national currency, financial flows that have been sent abroad are destabilized. Ukrainian e-commerce also faced problems, not just only in the occupied territories. Due to the restriction of Russian electronic payment systems, the level of financial flows is significantly limited. The cost of its formation becomes higher due to the use of financial intermediaries. The availability of bad loans for banking institutions is also problematic, which becomes a problem of repaying receivables for companies operating in hybrid conflicts. Thus, they need to reorganize the business model, because they should abandon the typical business models in order to adapt to external changing conditions. Problems related to investment activities are also essential for business, forasmuch as making wrong decisions is becoming more common due to the instability of the economic situation.

To date, the theoretical basis for the formation of management in a military or hybrid action is not created in the post-Soviet space. Currently, the problem is not relevant for many states; consequently, there is no demand for the formation of scientific research. In turn, after the activation of hybrid and military actions on the territory of Ukraine, this topic has received a sufficient level of scientific interest at the level of macroeconomics and international relations among Ukrainian researchers. At another point, the policy of Russia, highlighting hybrid warfare as a Ukrainian civil conflict, does not allow 
researchers to activate this field.

It is necessary to denote that Ukrainian scientists have not previously researched this topic on the corporate management level. Thus, this study is of important theoretical and practical value. According to the authors' viewpoints of the present academic paper, the development of theoretical fundamentals of management in conditions of hybrid conflicts should be a component of risk management. Furthermore, this research can also form part of emergency management, which has not received enough attention, although the practical need exists. At the same time, considering that military actions are often long-term, this topic should be a component of strategic management, especially, in countries characterized by military instability.

For all the reasons outlined, the main novelty of the study lies in developing a mechanism for managing financial security under hybrid conflict in eastern Ukraine based on international experience in hybrid wars. Moreover, this study has a practical meaning, as financial analysts and anti-crisis managers can use it to develop business in temporarily occupied territories.

\section{Research Methods}

The mechanism of companies' financial security management under hybrid conflicts is based on a study of scientific papers, which determine the features of the financial security management mechanism formation and adapt them to the conditions of hybrid conflicts. Interviews of Ukrainian and foreign business people, politicians, and the military, which have provided practical pieces of advice on modelling business behaviour in hybrid conflicts, were also analyzed. At the same time, general scientific methods of cognition were used for conducting the empirical research. The number of risks identified by non-military means of influencing financial security was determined by analyzing and systematizing the scientific literature and open-source information. The obtained data were grouped by categorical purpose, which allowed making business risks classification caused by hybrid conflicts, forming the study's novelty. By using deductive and inductive methods, the functional features of the financial security management mechanism subjects were developed, which at the same time reflect the sequence of implementation of financial security measures in hybrid conflicts. Using deductive and inductive methods also allows proposing measures to improve financial security with their classification by functional components, forming the study's novelty. By the way, methods of mathematical and statistical analysis were also used in the study. In particular, state financial security indicators were planned with the definition of averages, the application of trend analysis, and trend equation. Using the Pearson coefficient, the study's relevance was proved, based on the hypothesis that the lower the level of hybrid conflict is, the higher the level of Ukrainian enterprises' financial security is. All the calculations were made using Excel. Graphic methods and infographics were used for the visual presentation of the research results.

\section{Research Results}

Analysis of the research has shown that any conflicts lead to economic destabilization in general and the activities of individual businesses in particular. For proving this fact, let's continue the study of Kravchenko \& Pinchuk [2] and get the latest global peace index rank [3]. According to the results of the analysis, it can be concluded that in recent years Ukraine has been rapidly raising its position and in 2020 ranks 142 of 163 countries, having received the world index at the level of 148. Let's determine the planned indicators of the level of financial security based on the data of the Ministry of Economy and Trade for 2014-2018. The growth rate of the financial security indicator is calculated by the determination of the equation of the time series.

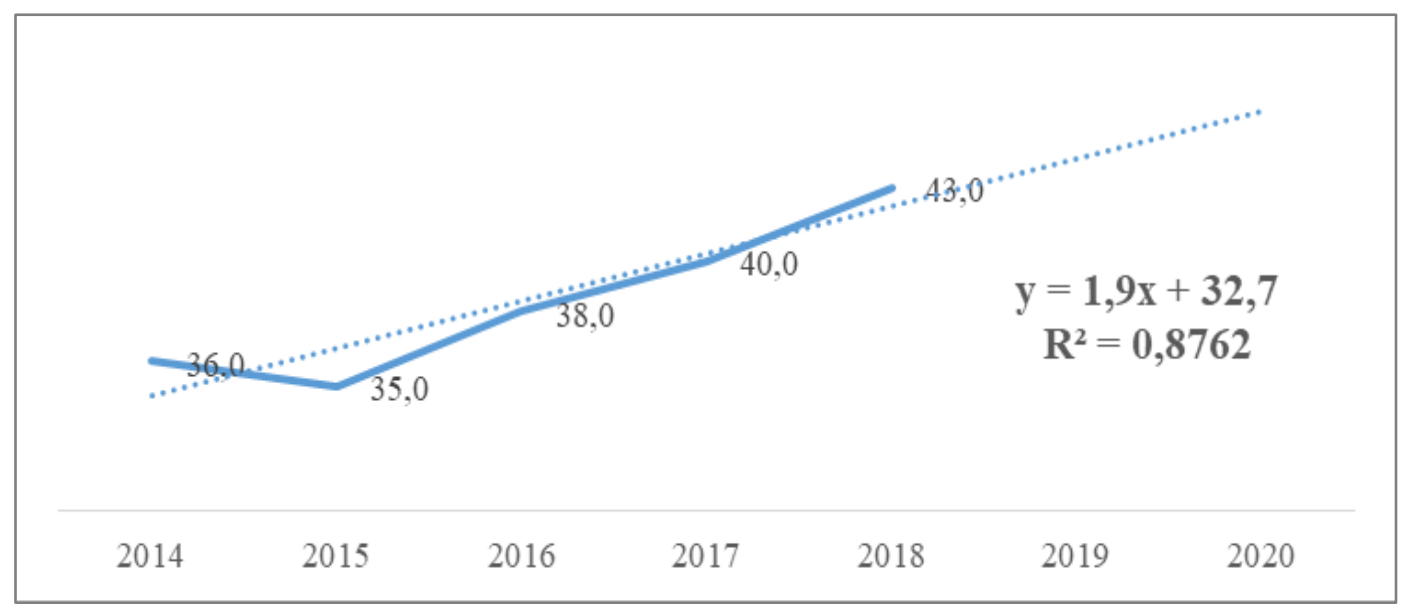

Figure 1. Ukraine's financial security level for 2014-2020 [23] 
Table 1. Comparison of the financial security level and peace index of Ukraine for 2013-2020 [3,23]

\begin{tabular}{|c|c|c|c|c|c|c|c|}
\hline Indicators & $\mathbf{2 0 1 4}$ & $\mathbf{2 0 1 5}$ & $\mathbf{2 0 1 6}$ & $\mathbf{2 0 1 8}$ & $\mathbf{2 0 1 9}$ & $\mathbf{2 0 2 0}$ & Pearson's ratio \\
\hline $\begin{array}{c}\text { Financial security } \\
\text { indicator }\end{array}$ & 36 & 35 & 38 & 43 & 45 & 47 & $-0,17$ \\
\hline Peace Index & 144 & 152 & 156 & 152 & 150 & 148 & \\
\hline $\begin{array}{c}\text { Financial security growth } \\
\text { rate,\% }\end{array}$ & $-28,0$ & $-2,8$ & 8,6 & 7,5 & 4,7 & 4,4 & \multirow{2}{*}{$\mathbf{0 , 9 7}$} \\
\hline $\begin{array}{c}\text { Peace Index, growth } \\
\text { rate \% }\end{array}$ & 53,2 & 5,6 & 2,6 & $-1,9$ & $-1,3$ & $-1,3$ & \\
\hline
\end{tabular}

Equation of the time series of the level of financial security is as follows:

$y=1.9 x+32.7$, where

$\mathrm{y}$ - financial security level;

$\mathrm{X}$ - the study period.

Thus, substituting the values of the sixth and seventh periods, corresponding to 2019-2020, we obtain indicators to compare the equation of financial security and the peace index.

Taking into consideration the correlation dependence between financial security and the peace index $(-0,97)$, which is based on empirical research, the lower the level of hybrid conflict is, the higher the level of financial security of Ukrainian enterprises is.

The impact of hybrid warfare on business arose in 1991 when the US National Council reported that the world's economies were overly dependent on computers, posing many threats to information security and financial flows. Speaking of hybrids conflicts, its main fundamental principle was to focus on businesses. Such a war is often called a gray war, where actions are deliberately restrained below a situation that would provoke a real, great war.

Thus, the primary purpose of the hybrid conflict is to undermine the national economy and disrupt the work of economic entities, which are vital to the economy through the use of non-military means.

Non-military means are a set of social institutions (organizations), legal norms, spiritual values, information, and general-purpose technical systems used by the state to act on internal and external relations to strengthen military security [9]. They help attract additional forces, including gaining allies, mitigating and eliminating military threats and dangers (contracts, agreements, turning enemies into neutrals, etc.).

Along with this, they reduce the capabilities of the aggressor (isolation, creating a negative image in public opinion, exposing plans, etc. further). They act as assistants and even substitutes (under certain conditions) for military forces [10]. Each type of non-military means has a variety of tools. All of them perform certain functions; they are divided into two large groups by affiliation, namely:
- $\quad$ state instruments of influence

- private or custom impact tools [9].

Most of the risks associated with military action are studied, while hybrid risks require further research. Quite often, they cannot be identified, avoided, or eliminated. However, it does not mean that such risks cannot be combated. Every company has the potential to prevent threats because they can always find a suitable development scenario, which is based on the creation of unique financial security methods. It is necessary to consider the basic rule that, regardless of what actions are taken to overcome the risks, there is no $100 \%$ guarantee that the company will provide financial or economic security [13]. However, an assessment of hybrid threats is necessary. In particular, based on the classification represented in Fig. 2, it is necessary to find those risks and dangers that correspond to the activities of the desired entity and consider possible risks that are not foreseen in this study due to their uniqueness. Let's define the main risks giving rise to non-military means that can influence the enterprise's financial safety in the conditions of hybrid conflicts (Fig. 2).

In business, the primary security tool is intelligence. Using intelligence tactics, methods, and procedures, companies can anticipate a hybrid threat while planning. International experience in waging such wars makes it possible to obtain effective mechanisms for counteracting these actions in building the financial security mechanism. The most obvious examples of a hybrid war in recent years, apart from the war in eastern Ukraine between Ukraine and Russia, are Russia's influence on the 2016 US presidential election. In addition, China's influence on the US economy through space racing is significant [8]. Hoffman S. [8] emphasizes the dangers of using equipment created in competing countries, as it can transmit valuable information and act as a tool for intelligence and surveillance. The enterprise should understand all the possible risks of cooperation with hostile countries or companies' representatives in this situation. A mature approach to countering such influence is strengthening cybersecurity, especially, for companies purchasing products from an enemy country (companies). 


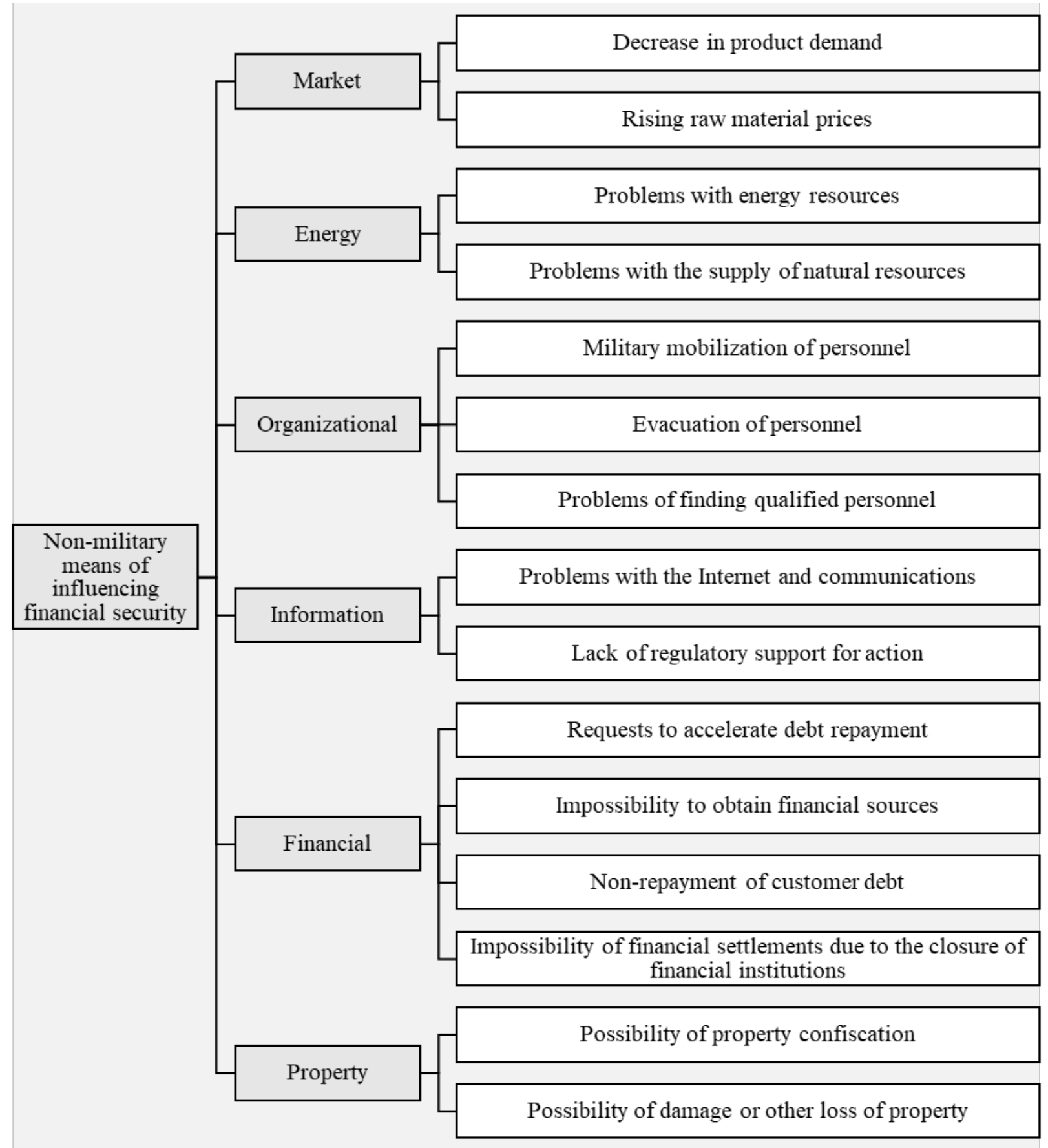

Source: developed by the author

Figure 2. Classification of risks created by non-military means of influencing the companies' financial security under hybrid conflicts

If we talk about Ukraine, the close business relations between Ukrainian and Russian businesses have been built for decades; consequently, waging a hybrid war does not allow breaking it entirely forasmuch as there is a threat of stopping the viability of this whole region. That is why, if companies do not plan to move their business to more stable areas, they will have to adapt to a risky, ever-changing environment, creating unique business models using traditional and non-traditional methods. In addition to forming tactical and operational response plans, existing enterprises should think about strategic plans in order to ensure financial security under the conditions of a hybrid war forasmuch as developments in eastern Ukraine remain unpredictable as of 2021.

Let's consider the international experience of doing business under the conditions of a hybrid conflict. As part of the global program of the World Economic Forum on Conflict and Violence, a conference was held with ten global companies and organizations working under a hybrid war. In particular, the experience of the companies 
from Afghanistan, Bangladesh, Burkina Faso, Congo, Nigeria, and Uganda [12] provide an opportunity to obtain recommendations for Ukrainian companies that have faced the crisis in the East of Ukraine. All companies work in the energy resources area, which helps domestic researchers adopt such an experience of overcoming the problem in building a development strategy for the Eastern region of Ukraine. These companies shared their methods of making financial security within the conditions of a hybrid war. The main one is the establishment of a partnership between the state and the enterprise. Under such war conditions, the enterprise has to remain economically crucial for the region where military or hybrid actions are carried out.

Cooperation with public authorities allows for creating helpful business for the society (Ortiz, 2020). The price of such cooperation is additional payments from profits to support military operations. In turn, the state provides guarantees for the support and development of this business, ensures its protection with the armed forces' involvement, shares the necessary information, and provides the legal and institutional capacity to resolve situations arising from hybrid conflict actions. Once cooperation with the state is established, certain protection mechanisms can be obtained to reduce the impact of the most critical factors, including energy security, property conservation, and information support. In addition, it helps develop an internal mechanism for companies' financial security management. According to domestic scientists' viewpoints, the mechanism of financial security management is a system of goals, functions, principles, methods, tasks, and management tools. They interact and aim to create conditions for sustainable development in the current and future periods. They also amplify its financial interests' protection by developing and implementing an effective financial strategy, flexibility in economic decision-making, timely response to external and internal threats, and effective risks management [11]. The enterprise's financial security management mechanism should be based on developing appropriate scientific theory, concept, strategy, and tactics and adequate monetary policy, using financial security methods and techniques. Theoretical aspects of the mechanism of financial security management of the enterprise are represented in Fig.3.

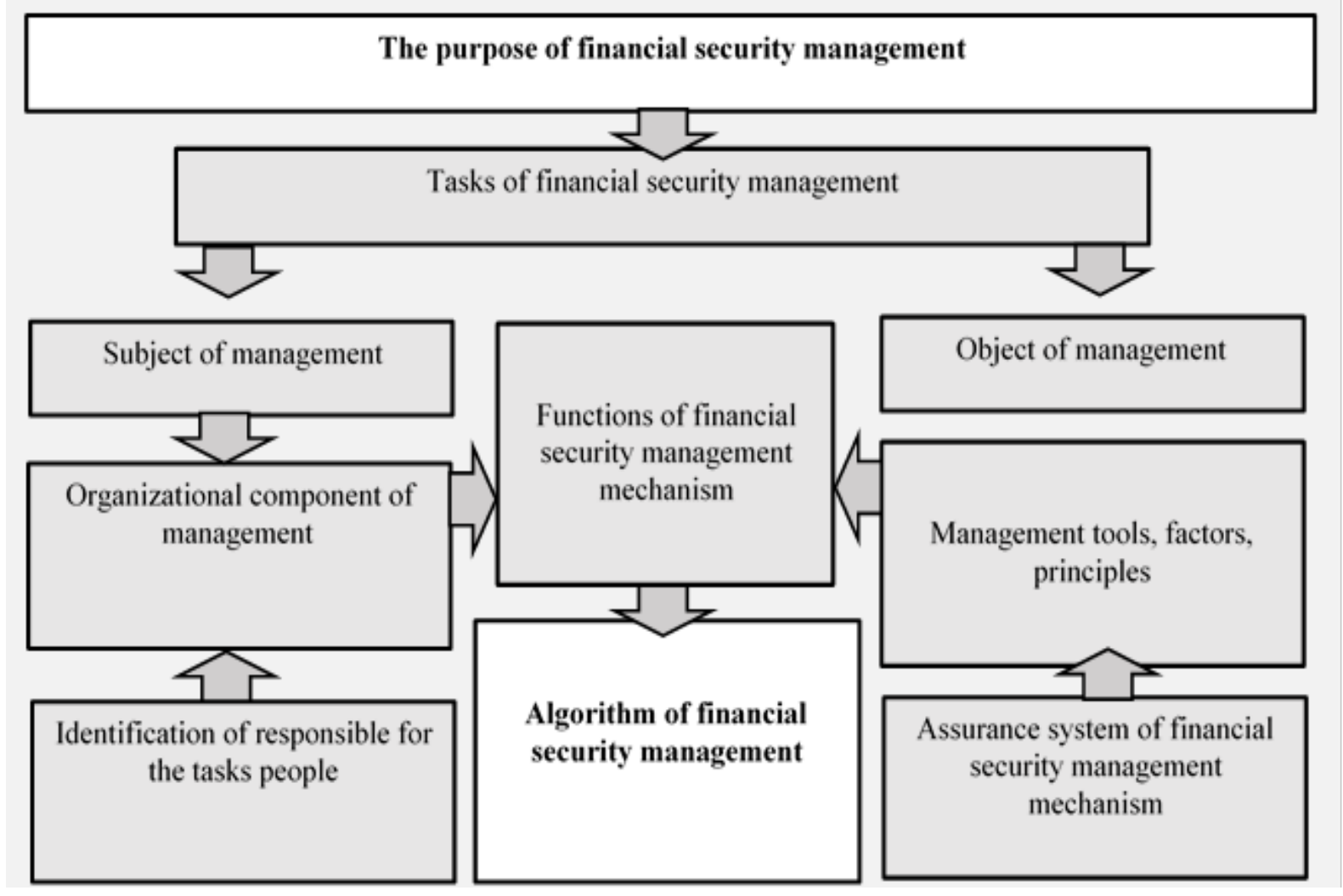

Source: compiled by the author

Figure 3. Theoretical scheme of the companies' financial security mechanism under hybrid conflicts [11] 


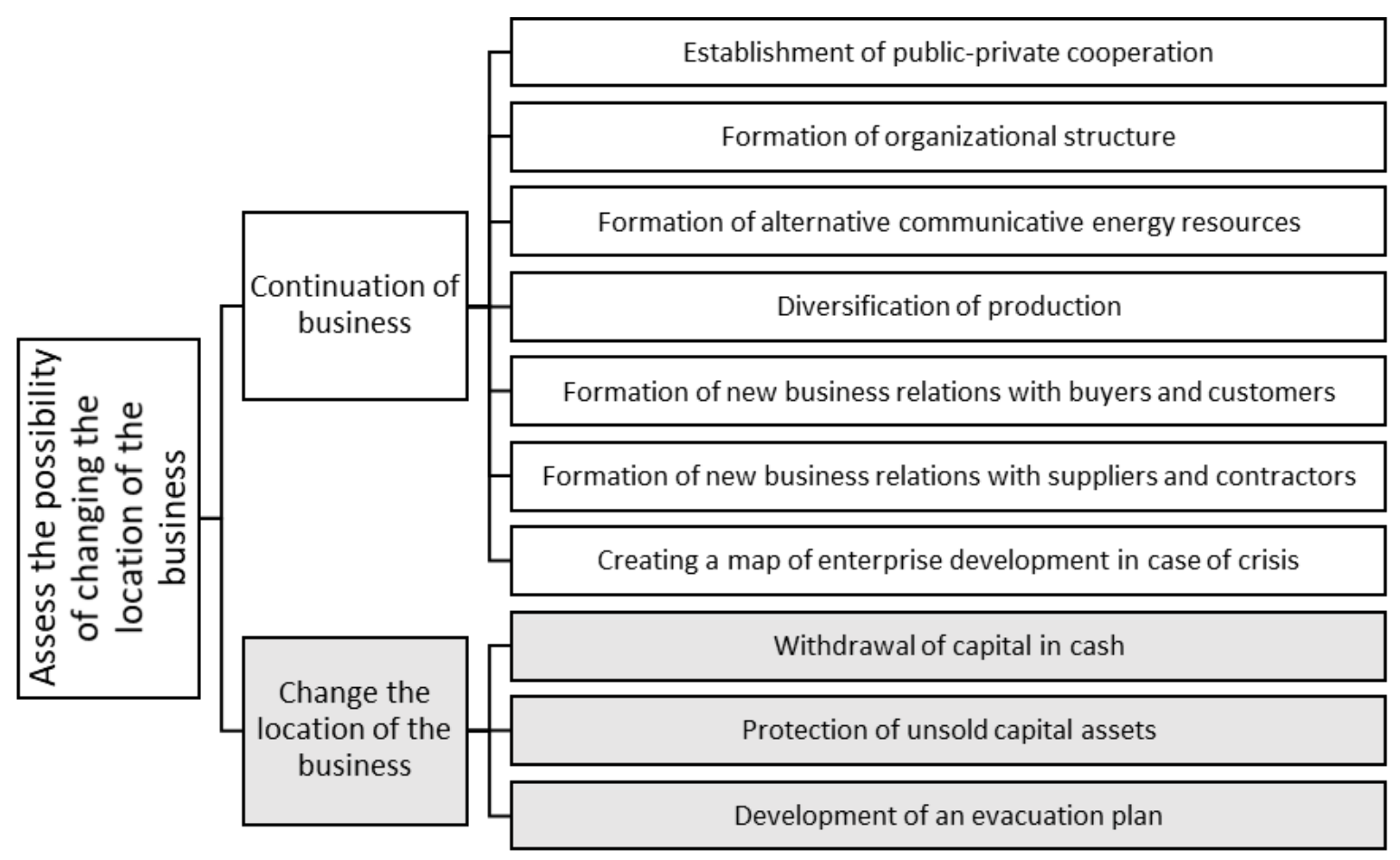

Source: developed by the author

Figure 4. Functions of financial security management entities in hybrid conflicts [14]

The proposed financial security management mechanism is implemented through the influence on the object of management by the subject [11]. The management subjects are the heads of the enterprise, financial service, accounting, personnel engaged in the production and maintenance of production processes. In the process of creating a mechanism for managing the financial security of enterprises in hybrid conflicts, it is essential to find responsible persons who will take action to reduce financial and other risks.

The objects of management include economic relations in the enterprise, which may consist of financial flows. Financial flows are provided by the mechanism of control of material, intangible and monetary resources. Building a financial security management mechanism at the enterprise aims to guarantee the enterprise's financial stability and protect its economic interests from external and internal threats and financial risks in order to ensure effective development in the current and long term [11].

The main objectives of the company's financial security process lie in providing timely detection and elimination threats to the financial security of the enterprise, as well as ensuring adequate financial risks management [11].

The following functions should be performed by the management subjects when performing actions on the management objects in case of crises due to hybrid conflicts (Fig.4).

At the preparatory stage of the financial security management mechanism, business preservation and development directions are determined. First, enterprises should assess the risk level and determine whether they should change the geolocation or continue operating within their region. If the company decides to change the area, the enterprise should ensure as follows:

1. Withdrawal of capital in cash. If there is a need to change the location of the business, all possible actions are taken to convert capital into cash. At the same time, quick-liquid and medium-liquid assets are the easiest ones for their conversion into cash. On the other hand, it will be the most difficult to convert capital investments into money, especially when it comes to capital buildings and real estate. Within the conditions of a hybrid war, the sale of such assets is either impossible or possible at a much lower price. That is why a change of location leads to significant losses.

2. Additional protection of unsold capital assets by signing agreements with security organizations on the protection of assets.

3. Development and implementation of an evacuation plan for people who will move together with business.

Supposedly, a company decides to continue its activities in a hybrid conflict. In that case, firstly, it is necessary to develop a program (regulations or provisions) in hostilities using traditional military operations. Next, an anti-crisis business passport should restructure the business model following the new external environment. Finally, financial security management entities should take the following steps. 
1. Taking into consideration the possible changes in the administrative and political environment, it is necessary to establish cooperation with local governments, which should feel the importance of business for the region. Furthermore, it is important to assess the state of the company's financial security and reveal what part of the profit can be directed to regional development. In turn, this will allow obtaining government support and guarantees that can be provided in the context of hybrid conflicts.

2. Creating a crisis organizational structure of the enterprise. First of all, the company managers have to study the ideological mood within the team, forasmuch as the events of 2014 have shown that even in the same team, one part is ready for evacuation, and the other is not. Accordingly, those who plan to evacuate should be fired, and work should continue with those who remain in the team.

3. Identifying the opinion leaders ready to support business processes, recruiting new employees to work according to the new business scheme.

4. Working out internal communications in case of hostilities, including the possibility of using alternative sources and information support.

5. Providing alternative energy sources.

6. It is necessary to study the plan of product diversification according to the local market's needs, including with maintenance of preparation of technical maintenance.

7. Building new types of business relationships reducing the risks of insolvency. For example, it is necessary to arrange payment for products on the day of delivery. In turn, the purchase of materials is carried out on the same basis.

8. Determining the map of business development, taking into account possible military actions, public riots, looting, and growth of the criminal component in the region.

9. Creating maps of enterprise development in case of mobilization or death of the head or key responsible business persons.

10. Developing measures to protect assets further, forasmuch as conventional measures during hostilities are not sufficient.

The functional component of the mechanism reflects the sequence of the mechanism implementation.

Effective management of financial security is possible provided that it is assessed in a timely and objective manner. For this reason, the next step is to assess the financial security of the enterprise that uses the traditional methodology for evaluating the financial security based on determining liquidity, financial condition, and profitability indicators. It is also advisable to consider indicators of social security, especially, material incentives for staff, forasmuch as it's the basis for doing business within the conditions of a crisis. Finally, the company analyses the correspondence of the actual financial security level to an acceptable one.

Supposedly, the actual level corresponds to the allowable. In that case, there is a transition to the last stage of the management system, namely, to monitor compliance with the appropriate level of the company's financial security. If the actual level does not correspond to the permissible level, it is necessary to select measures to increase financial security and assess their economic efficiency by calculating the costs of their implementation and the benefits of minimizing the financial risks. In order to substantiate the main directions of increasing the enterprise's financial security level under hybrid conflicts, it is necessary to systematically approach the problem's solution and consider such measures for the functional components of financial security (Table 2).

Therefore, if the company takes measures to improve its financial security, the next step is to determine the level of achieving the goal. If the plan has not been achieved, then a return to the initial stage of the algorithm is carried out. The full achievement of the goal indicates an increase in the company's financial security. Partial achievement of this goal suggests an increase in the enterprise's financial security level but impossibility to achieve the desired result, which indicates the need for further management by developing new improving measures. All these measures should be consistent with each other, forasmuch as using one method can reduce or increase the level of financial risks in other areas of the company's economic activity. Therefore, integrated improvement measures will be the most effective.

All proposed increasing financial security measures are presented in general. For each enterprise, such actions are individual and require consideration of different activities and the specifics of its economic relations with other counterparties. After selecting the optimal measures, it is necessary to coordinate and monitor the implementation of targets. Timely detection of errors and miscalculations allows minimizing the costs of achieving this goal. Monitoring is used to systematically control changes in indicators and determine the effectiveness of implemented measures.

The implementation of the proposed algorithm will help optimize the financial security management system of the enterprise in conditions of hybrid conflicts. 
Table 2. Measures to increase the level of company's financial security under hybrid conflicts

\begin{tabular}{|c|c|c|}
\hline $\begin{array}{l}\text { Functional } \\
\text { components }\end{array}$ & $\begin{array}{c}\text { Measures to increase financial } \\
\text { security } \\
\end{array}$ & Impact on financial security \\
\hline \multirow{3}{*}{ Budget component } & Changing the tax system & $\begin{array}{l}\text { Prompt response to changes in taxation in accordance with new } \\
\text { implementations, work on tax optimization }\end{array}$ \\
\hline & $\begin{array}{l}\text { Use of state business support in } \\
\text { war-torn areas }\end{array}$ & $\begin{array}{l}\text { Prompt response to the possibility of obtaining public funding at low or zero } \\
\text { interest rates for capital recovery }\end{array}$ \\
\hline & $\begin{array}{c}\text { Profit distribution policy to support the } \\
\text { territory }\end{array}$ & $\begin{array}{l}\text { Constant control over the costs of financial support of the territory in order to } \\
\text { ensure liquidity and solvency of the enterprise }\end{array}$ \\
\hline \multirow{3}{*}{ Credit component } & Accounts receivable management & $\begin{array}{l}\text { Reducing the number of buyers and conspirators who do not work on terms of } \\
\text { payment on the day of receipt of products, and use commodity loans }\end{array}$ \\
\hline & $\begin{array}{c}\text { Improving the payment discipline of } \\
\text { the enterprise }\end{array}$ & $\begin{array}{l}\text { Constant control over the preservation of liquidity and cash discipline, which } \\
\text { make it possible to remain solvent }\end{array}$ \\
\hline & Balanced loan policy of the enterprise & $\begin{array}{l}\text { Refusal of non-performing loans, in particular, in foreign currency against the } \\
\text { background of inflation }\end{array}$ \\
\hline \multirow{2}{*}{ Personnel component } & Assistance to employees & $\begin{array}{l}\text { Organization of material assistance to employees, assistance in evading } \\
\text { mobilization, which leads to a decrease in staff turnover }\end{array}$ \\
\hline & Update of human resources & $\begin{array}{l}\text { Search for talented people against the background of massive business } \\
\text { closures that will increase the innovative potential of the enterprise }\end{array}$ \\
\hline Production component & Product diversification & $\begin{array}{l}\text { If there are government programs to support some areas of activity, possible } \\
\text { product diversification should be considered }\end{array}$ \\
\hline \multirow{2}{*}{ Sales component } & Changing the audience & $\begin{array}{l}\text { Reorientation of products to middle-income customers who are more } \\
\text { risk-tolerant }\end{array}$ \\
\hline & Use of e-commerce tools & $\begin{array}{l}\text { The use of e-commerce provides an opportunity to expand sales channels and } \\
\text { ensure a stable inflow of funds }\end{array}$ \\
\hline \multirow{2}{*}{ Monetary component } & Currency discipline & $\begin{array}{l}\text { Increase in the circulation of foreign currency and liquid assets, which allows } \\
\text { not to lose funds from the depreciation of the national currency }\end{array}$ \\
\hline & $\begin{array}{c}\text { Release of long-term financial } \\
\text { resources }\end{array}$ & $\begin{array}{l}\text { Ongoing work on finding opportunities to sell real estate and other property } \\
\text { with a long liquidity period to ensure business mobility }\end{array}$ \\
\hline Intangible component & Advertising and media activity & $\begin{array}{l}\text { Constantly informing the community about the support policy of the region } \\
\text { allows to improve the reputation and increase the value of business }\end{array}$ \\
\hline \multirow{4}{*}{ Insurance component } & $\begin{array}{l}\text { Increasing the level of insurance } \\
\text { protection of the enterprise }\end{array}$ & Increased insurance costs, which will save assets as a result \\
\hline & $\begin{array}{c}\text { Creating reserves in case of unforeseen } \\
\text { situations }\end{array}$ & Constant accumulation of fast-liquid funds and their transfer to safe places \\
\hline & $\begin{array}{l}\text { Selection of reliable security } \\
\text { companies }\end{array}$ & $\begin{array}{l}\text { The choice of reliable security companies, increasing the level of preservation } \\
\text { of property }\end{array}$ \\
\hline & Cooperation with the government & State support allows to receive information and insurance support \\
\hline
\end{tabular}

Source: compiled by the author

\section{Discussion}

Despite the scientific and practical justification of the study, three issues remain debatable, namely:

- on the relevance of anti-crisis measures for the company within the conditions of a "hybrid conflict" in Ukraine.

- on the possibility of geographical change of business as a direction of ensuring the financial security;

- opportunities for public-private cooperation between the newly created authorities as the main direction of the financial security formation.

This study is based on the recommendations of nationally significant large companies operating in the context of hostilities, which are collected by the World Economic Forum [12]. Such enterprises also exist in the occupied territories of Ukraine. First of all, these are retail chains owned by influential business owners in Donbas. In the second place, these are companies manufacturing strategic products. Without doubt, it is also impossible to live in these regions without small service companies. These are catering and recreation facilities. All these enterprises operate under the constant threat of shelling, which occurs from time to time, even though Ukrainian scientists interpret the situation in the occupied territories as a "hybrid conflict" or "hybrid war" $[1,4,6]$

Taking into consideration that full-fledged military action may take place in the territory of economic activity, some scholars interpret the situation as a military conflict [17]. In conditions of military conflict, the issue of developing financial security measures becomes impractical, forasmuch as under such circumstances, companies are forced to close because of the threat to life. It is confirmed by the lack of scientific research aimed at strategies for the enterprise in an armed conflict. According to the Ministry of Justice of Ukraine, about 100,000 enterprises out of 300,000 registered in the occupied territories were eliminated. Despite the supportive policy of the Government of Ukraine towards entrepreneurs from the occupied territories and the creation of the Ministry of Reintegration of the 
Temporarily Occupied Territories, which stimulates internal business movement, most entrepreneurs are not ready to move from the conflict zone. Of the 400,000 registered business units, only 3,000 entrepreneurs chose to change their geographical location [16]. This indicates that the possibility of economic activity in the region is provided and guaranteed by the local government, confirming the research's relevance. Although a successful practice of business-to-state cooperation on a global scale is observed, there is another experience where militants take away businesses while taking control over them [19]. This experience of some countries and even Ukrainian enterprises deny the possibility of anti-crisis development in general.

\section{Conclusions}

Thus, the enterprise's financial security management mechanism is formed by defining the main goal and the corresponding tasks, the implementation of which will lead to the achievement of goals. In the theory of mechanism development, there is an organization of subjects' influence on the object. In this case, depending on the financial problem that arises in the company suffering from hybrid conflicts, a sequence of specific actions meets the goal. The present study proposes the functional characteristics of the financial security subjects, which are performed consistently to maintain and restore financial stability, liquidity, profitability, or other indicators of the enterprise's efficiency. The paper develops two enterprise development scenarios depending on the owners' choice to change the geographical location of the business or stay to work under the conditions of conflict. As a basis for improving financial security, it is recommended to establish public-private cooperation and create socially significant products or be a socially important organization in the territory subject to hybrid conflicts. As a result, a number of measures are proposed, including recommendations for improving the budget, credit, personnel, production, sales, monetary, intangible, insurance components of the functional support of the financial security management mechanism.

\section{REFERENCES}

[1] Z. Varnalii, T. Tomashevskij, "Financial Security Of Ukraine in Hybrid War," Bulletin of Taras Shevchenko National University of Kyiv Economics, vol. 3 (204), 2019. (DOI: https://doi.org/10.17721/1728-2667.2019/204-3/1)

[2] O. Kravchenko, S. Pinchuk, "Financial security of business entities as a reflection of the state of the external environment," Effective economy, vol. 6, 2020. (DOI: https://doi.org/10.32702/2307-2105-2020.6.6)
[3] "Global Peace Index 2021: Measuring Peace in a Complex World," Institute for Economics \& Peace, Sydney, 2021, (URL:

https://www.visionofhumanity.org/wp-content/uploads/202 1/06/GPI-2021-web-1.pdf)

[4] N. Zachosova, "Threats to Financial Institutions Economic Security Under Hybrid Warfare and European Integration," Prospects for managerial activity of business entities in the context of economic security: Materials of the International Security Forum, Cherkasy, May 25-27, 2017, p. 157-159.

[5] L.M. Gerasina, V.L. Pogribna, I.O. Polishchuk, "War "hybrid"," Political Encyclopedic Dictionary, Kharkiv: Right, 2015.

[6] K. Popovych, "Hybrid war as a modern way of warfare: historical and modern dimensions," Scientific Bulletin of Uzhgorod University, Series "History", vol.2 (35), 2016.

[7] M. Eggleton, "Hybrid war targets business," Financial review, 2019. (URL: https://www.afr.com/companies/finan cial-services/hybrid-war-targets-business-20191022-p5331 h)

[8] S. Hoffman, "Engineering global consent: The Chinese Communist Party's data-driven power expansion," ASPI, 2019. (URL:https://www.aspi.org.au/report/engineering-gl obal-consent-chinese-communist-partys-data-driven-power -expansion)

[9] D. Fisher D, "Non-military aspects of security: a systems approach," Moscow: Branovsky Publishing House OJSC, 2007.

[10] I. Panarin, "Information warfare and diplomacy," Moscow: JSC "Publishing House Gorodets", 2009.

[11] O. Malyk, "Conceptual basis for the formulation of the mechanism of management of financial security of the enterprise," University of Science Notes, vol. 64, 2017.

[12] R. Muggah, E. Golberg, "6 lessons from companies operating in war-torn communities," World Economic Forum, 2016. URL:https://www.weforum.org/agenda/201 6/03/6-lessons-from-companies-operating-in-war-torn-com munities/

[13] M. Ortiz, "Hybrid Threats against Companies" Tarlogic cybersecurity expert, 2020. (URL: https://www.tarlogic.com/blog/hybrid-threats-against-com panies/2

[14] S. Pogrebny, "Step-by-step plan. How businesses prepare for war," Business, 2021, (URL: https://biz.nv.ua/experts/ kak-podgotovit-biznes-k-voyne-sovety-eksperta-novosti-u krainy-50155939.html)

[15] A. Eisenberg, "Business during the war. Ten tips from an Israeli spy," Business League, 2015, (URL: https://biz.liga.net/all/it/article/izrailskiy-rozvedchik-10-so vetov-kak-vesti-biznes-vo-vremya-voyny)

[16] D. Gutsulyak , "Summary of the Ministry of Defense of Ukraine on the situation in the area of the Joint Forces operation," Interview, Ministry of Defence of Ukraine, 2021.

[17] N. Vyhovska, A. Polchanov, "Assessment of losses of Ukraine's financial potential from the military conflict," Accounting and Finance, 4, 2019. 
[18] S. Rugumamu, "Capacity development in fragile environments: Insights from parliaments in Africa," World Journal of Entrepreneurship, Management and Sustainable Development, 7 (2), 2011, (DOI: https://doi.org/10.1108/20 425961201000034)

[19] B. Ganson, A. Wennmann, "Business and conflict in fragile states," Adelphi Series, 55:457-458, 11-34, 2015, (DOI: https://doi.org/10.1080/19445571.2015.1189153)

[20] A. Rettberg, "Local Business and the Political Dimensions of Peacebuilding," Local Business, Local Peace: The Peacebuilding Potential of The Domestic Private Sector, London: International Alert, pp. 38 - 72, 2006.
[21] O. Petryna, "Regulatory and legal regulation of financial security of the enterprise: assessment and areas for improvement," Scientific Bulletin of Lviv State University of Internal Affairs, 1, 2011.

[22] A. Ramskyi, A. Solonko, "Mechanism of formation of financial security of an enterprise," European scientific journal of Economic and Financial innovation, "European Association of Economists", 1, 14-20, 2018, (DOI: https://doi.org/10.32750/2018-0102)

[23] "Level of economic security," in Information and analytical materials for 2014-2018, Ministry of Economic Development and Trade, 2019, (URL: https://dostup.pravd a.com.ua/request/rivien_iekonomichnoyi_biezpieki) 